\title{
ASSESSMENT OF THE INTEGRATION OF MECHANICAL WEEDING FOR WEED CONTROL IN SUGAR BEET-GROWING
}

\author{
Fabienne RABIER ${ }^{1}$, Marie STAS ${ }^{1}$, Barbara MANDERYCK ${ }^{2}$, Bruno \\ HUYGHEBAERT ${ }^{1}$ Quentin LIMBOURG ${ }^{1}$ \\ ${ }^{1}$ Walloon Agricultural Research Centre, Gembloux, BELGIUM \\ ${ }^{2}$ Royal Belgian Institute for Beet Improvement (IRBAB), BELGIUM \\ E-mail of corresponding author: f.rabier@cra.wallonie.be
}

Keywords: mechanical weeding, integrated weed management, sugar beet, costs, effectiveness

\begin{abstract}
The aim of this research was to evaluate the potential of mechanical weeding for the cultivation of sugar beet by comparing four weed control programmes (one chemical, two mixed (chemical and mechanical) and one mechanical). Under the dry conditions of 2017, the mixed conditions displayed the best effectiveness (more than 97\%), using less herbicide and costing $€ 30 /$ ha less than the chemical scheme, while producing a yield identical to that obtained with fully chemical protection. Conversely, the mechanical programme was ineffective $(69 \%)$, especially on weeds in the crop row (23\% effectiveness only); while its cost was lower ( $€ 180 / \mathrm{ha}$ ), it led to a loss of sugar yield of $18.9 \%$ compared to chemical weed control.
\end{abstract}

\section{INTRODUCTION}

Plant protection products have a recognised impact on the environment (air, soil, surface water, groundwater and seawater pollution), and are toxic to varying degrees (Calvet et al., 2005). Herbicides are applied to plants at an early stage of development, and are therefore more easily transported to surface water and groundwater. According to the key indicators for the Walloon environment (DGARNE, 2014), pesticides are detected in twothirds of groundwater quality control sites, and the active substances found in higher concentrations are all herbicides. Representing 36,679 ha of land in 2016, beet is an important crop in Wallonia, but makes heavy use of pesticides (mainly herbicides): an average of $6.5 \mathrm{~kg}$ of active substances per hectare (Lievens and al., 2014). The control of weeds is essential in beet-growing, as the plant's slow juvenile growth leads to strong competition from weeds which potentially has a significant impact on yields of up to $90 \%$. More specifically, there are number of problems associated with the herbicide solutions used for beet-growing, including the appearance of resistance, in particular in fat hen (Chenopodium album) (Mechant and al., 2008) and spreading orach (Atriplex patula) (De Cauwer et al., in press), and the reduction of available active substances and authorised doses. In response to these problems, one solution for farmers is integrated weed management, in which various approaches to managing weeds are combined. In this context, mechanical weeding is a clearly identified technique which has benefited in recent years from developments which facilitate its implementation, such as camera or GPS guidance, increased working widths and the introduction of equipment for working on the crop row itself. Trials have shown that it is possible to control weeds in integrated systems combining mechanical weeding and phytosanitary treatment, even for beetgrowing, which is highly demanding in terms of weed competition (ITB, 2011, Kunz et al., 2015). However, problems remain due to lack of flexibility in the application of treatments, observed crop losses and lack of effectiveness (Pottier M., 2012; Colomb et al., 2011; ITB, 2011). Questions may be legitimately asked about the cost of implementing these practices. The available studies show variable results depending on 
whether direct costs and/or some indirect impacts are taken into account (ITB, 2011; ITAB, 2012). Considerable variability is also observed according to the pedoclimatic conditions.

The objective of the trial was to evaluate the potential of mechanical weeding for the cultivation of sugar beet in order to provide farmers with information on the effectiveness and cost of combined weed control in Walloon pedoclimatic conditions.

\section{MATERIAL AND METHOD}

The trial was set up on 27 March 2016 (variety BTS990; inter-row distance $45 \mathrm{~cm}$; row width $18.6 \mathrm{~cm}$ ) on a plot located in Autre-Eglise. Four weed control programmes in four blocks with four passes per block were compared; the crops were treated identically in all other respects (Table 1).

Table 1. Description of the weeding treatments

\begin{tabular}{|l|c|c|c|c|c|c|c|}
\hline $\begin{array}{c}\text { Weeding } \\
\text { treatments }\end{array}$ & $09 / 04 / 17$ & $20 / 04 / 17$ & $27 / 04 / 17$ & $9 / 05 / 17$ & $16 / 05 / 17$ & $23 / 05 / 17$ & $31 / 05 / 17$ \\
\hline M0 - Untreated & $/$ & $/$ & $/$ & $/$ & $/$ & $/$ & $/$ \\
\hline M1 - Chemical & FAR 1 & FAR 2 & FAR 3 & $/$ & FAR 4 & FAR 5 & FAR 6 \\
\hline M2 - Mixed 1 & FAR 1 & FAR 2 & FAR 3 & $/$ & FAR 4 & $\begin{array}{c}\text { Hoe with } \\
\text { stars }\end{array}$ & $/$ \\
\hline M3 - Mixed 2 & FAR 1 & FAR 2 & FAR 3 & Hoe & $/$ & $\begin{array}{c}\text { Hoe with } \\
\text { stars }\end{array}$ & $/$ \\
\hline $\begin{array}{l}\text { M4 - } \\
\text { Mechanical }\end{array}$ & $/$ & $/$ & $/$ & Hoe & $\begin{array}{c}\text { Hoe + } \\
\text { rotative } \\
\text { weeder }\end{array}$ & $\begin{array}{c}\text { Hoe with } \\
\text { stars }\end{array}$ & $/$ \\
\hline
\end{tabular}

Given the dry conditions, there was no application of pre-emergence herbicides (due to the ineffectiveness of soil active herbicides. The FAR (Fenmedipham Activator Radiculair) treatments are listed in Table 2. Four different modes of action were used in this scheme.

Table 2. Description of the FAR treatments (products and quantities)

\begin{tabular}{|l|c|}
\hline \multicolumn{1}{|c|}{ FAR description } & Doses/ha et products* $^{*}$ \\
\hline FAR 1 (sowing + 12 days) & $0.81 \mathrm{Be}+0.51 \mathrm{G}$ \\
\hline FAR 2 (+ 11 days) & $11 \mathrm{Be}+0.61 \mathrm{P}+15 \mathrm{~g} \mathrm{~S}$ \\
\hline FAR 3 (+ 7 days) & $0.51 \mathrm{Bv}+0.21 \mathrm{~T}+0.61 \mathrm{P}+15 \mathrm{~g} \mathrm{~S}+0.051 \mathrm{Vsc}+0.51 \mathrm{H}$ \\
\hline FAR 4 (+ 20 days) & $0.61 \mathrm{Bv}+0.21 \mathrm{~T}+0.61 \mathrm{P}+0.11 \mathrm{Vsc}+0.51 \mathrm{H}$ \\
\hline FAR 5 (+ 7 days) & $0.61 \mathrm{Bv}+0.21 \mathrm{~T}+0.61 \mathrm{P}+0.151 \mathrm{Vsc}+0.51 \mathrm{H}$ \\
\hline FAR 6 (+ 7 days) & $0.51 \mathrm{Fr}+0.51 \mathrm{Vsc}$ \\
\hline
\end{tabular}

${ }^{*}$ Be : Betanal Elite (91 g PMP-71g DMP-112 g ethofumesate) - G: Metatron (700 g/l metamitron) - P: Chlordex (430 g/l chloridazon) - S : Safari (50\% triflusulfuron-methyl) - Bv: Belvedere (160 g/l phenmedipham $+160 \mathrm{~g} / \mathrm{l}$ desmedipham) $-\mathrm{T}$ : Ethomat $(500 \mathrm{~g} / \mathrm{l}$ ethofumesate $)-\mathrm{Vsc}:$ Venzar $(500 \mathrm{~g} / \mathrm{l}$ lenacil) - Fr : Frontier Elite (720 g/l dimethenamide-P) - H : Vegetop (812 g/l esterified oilseed rape oil).

Weed pressure was low: in June, the total average pressure was 16.2 weeds $/ \mathrm{m}^{2}$ on average in non-weeded controls, with an observed variability in the plot of 6.1 to 30.0 weeds $/ \mathrm{m}^{2}$. For the mechanical weeding, two machines were used. The first of these was a hoe mounted with a camera ( $3 \mathrm{~m}$, brand Carré, model Econet) which weeded between rows 
by means of triangular coulters and Lelièvre blades. In order to work on the crop row, the hoe could be equipped with stars when the beet stage made this possible ( $>6$ leaves). The second machine used was a $6 \mathrm{~m}$ rotative weeder (Einböck, Aerostar rotation model), consisting of teeth mounted on inclined discs fixed on independent suspended arms; this weeder worked over its entire width independently of the crop rows. The weed population was monitored throughout the season at each weed control intervention by conducting counts in $0.50 \mathrm{~m}^{2}$ sample squares distributed at random in the different conditions as well as in the non-weeded controls. The latter were distributed evenly throughout the plot to allow for the spatial variability in the distribution of weeds. In total, 96 sample squares were evaluated at each count for the total number of weeds and the number of weeds in the crop row and between the rows (with both species and stage being recorded). The number of beets was also counted after emergence, after each pass of a mechanical tool and at the end of the weeding season. Effectiveness (\%) represented the evaluation of the treatment's action on the weeds. It was calculated by comparing the number of weeds counted for a defined condition with the untreated control. This was done in each sample square, for the total number of weeds as well as for the weeds located in the crop row and between the rows, using the following formula:

$$
E f_{P 1}=100-\left(100 \times \frac{A d v P 1}{A d v T}\right)
$$

Where: $E f=$ effectiveness of plot 1 in $\%, A d v P 1=$ number of weeds $/ \mathrm{m}^{2}$ in plot 1 , and $A d v T=$ number of weeds $/ \mathrm{m}^{2}$ in the nearest untreated control.

Selectivity represented the impact of weed control on the beet, and was evaluated by calculating the $\%$ of beet losses compared to a previous situation.

For each block and in each condition, $6 \mathrm{~m} \mathrm{x} 4$ rows $\left(10.8 \mathrm{~m}^{2}\right)$ of beets were manually topped and lifted. The samples thus obtained were weighed before and after washing and analysed in order to determine the yield and quality of the beets (mellasigenic elements), and in particular their sugar content. Each weed control programme was subject to a cost calculation. This included the use of the machinery (the cost of the tractor, driver and machine) and the cost of the products. All calculations were carried out using the Mecacost software program (www.mecacost.cra.wallonie.be, Rabier et al., 2008). The assumptions used for the calculations are presented in ).

Table 3).

Table 3. Parameters used for the calculation of the weeding costs

\begin{tabular}{|l|c|}
\hline \multicolumn{1}{|c|}{ Parameters } & \multicolumn{1}{c|}{$\begin{array}{c}\text { Assumptions } \\
\text { UA : Annual Utilization }- \text { Perf : Performance }\end{array}$} \\
\hline Labour cost & $20 € / \mathrm{h}$ \\
\hline Hoe $(3 \mathrm{~m})$ & Price: 33000 to 43000 (with stars) $€-$ UA: 100 ha/year - Perf: 1,6 ha/h \\
\hline Rotative weeder $(6 \mathrm{~m})$ & Price: $14000 €-$ UA: 100 ha/year - Perf: 3,5 ha/h \\
\hline $\begin{array}{l}\text { Sprayer }(27 \text { m-trailed- } \\
3000 \text { litres })\end{array}$ & Price: $45000 €-$ UA: 800 ha/year - Perf: 7 ha/h \\
\hline Depreciation & On the technical lifetime of the machine regarding its specific annual utilization \\
\hline
\end{tabular}




\section{RESULTS AND DISCUSSION}

The two mixed conditions (M2 and M3) were the ones that worked best, with similar effectiveness scores of $97.75 \%$ and $97.28 \%$. This is explained by the conditions in spring 2017 , which did not restrict the use of mechanical tools and made it harder to control the more developed weeds (> 2 leaves) with herbicides, a situation that was successfully remedied with the use of the hoe to destroy weeds up to the six-leaf stage.

Table 4. Total, row and inter-row effectiveness (mean in \%, $n=16$ ), in June for the four weeding treatments \pm standard deviation $(\%)$

\begin{tabular}{|l|c|c|c|c|}
\hline $\begin{array}{l}\text { Weeding } \\
\text { treatments }\end{array}$ & M1- chemical & M2-Mixted 1 & M3-Mixted 2 & M4 - Mechanical \\
\hline $\begin{array}{l}\text { Effectiveness } \\
\text { (total) }\end{array}$ & $90.52 \pm 24.18^{* \mathrm{a}}$ & $97.75 \pm 3.68^{* * * \mathrm{a}}$ & $97.28 \pm 3.05^{* * * \mathrm{a}}$ & $69.71 \pm 19.65^{\mathrm{b}}$ \\
\hline $\begin{array}{l}\text { Effectiveness } \\
\text { (row) }\end{array}$ & $92.23 \pm 9.63^{* * * \mathrm{c}}$ & $94.74 \pm 7.85^{* * * \mathrm{c}}$ & $90.68 \pm 10.31^{* * * \mathrm{c}}$ & $23.70 \pm 21.87^{\mathrm{d}}$ \\
\hline $\begin{array}{l}\text { Effectiveness } \\
\text { (inter-row) }\end{array}$ & $89.80 \pm 19.46^{\mathrm{f}}$ & $98.95 \pm 4.17^{* \mathrm{eg} \mathrm{h}}$ & $100.00 \pm 0.00^{* * \mathrm{e} * \mathrm{~g}}$ & $97.68 \pm 3.61^{* \mathrm{e} \mathrm{h}}$ \\
\hline
\end{tabular}

Means quoted with different letters are significantly different at the level $\mathrm{p}<0.05\left({ }^{*}\right), \mathrm{p}<0.001\left(^{* *}\right)$ or $\left.\mathrm{p}<0.0001{ }^{* * *}\right)$

The chemical treatment condition achieved an effectiveness of $90.52 \%$ which, although disappointing, can be explained by the specific conditions encountered during the year. The cold, dry weather at the beginning of the season led to very slow beet development and caused the weeds to harden off; this was then followed by a sudden rise in temperatures combined with very rapid new weed emergence and development. The effectiveness of the completely mechanical condition was not acceptable, with an average of $69.71 \%$, significantly or very significantly different from the other three conditions.

A comparison of row and inter-row effectiveness shows that row effectiveness was lower. For condition M4, this was extremely problematic, with an effectiveness of $23.70 \%$ in the crop row, but $97.68 \%$ between the rows (a very significant difference from M1, M2 and M3 in the row). It is thus clear that the limitation of mechanical tools lies in their ineffectiveness against weeds situated in the row. It is hard to strike a balance between the reasonable development of beet and weeds with a view to destroying the latter without damaging the main crop.

The failure to perform a late application of soil acting herbicides (M2, M3 and M4) had no impact on weed development after June. A count conducted on 1 September revealed no difference from the situation in June. This may be explained by the particularly dry conditions and the incorporation of the soil acting herbicides preventing late emergence of weeds (e.g. lenacil) as early as FAR3.

With regard to selectivity, there were no significant losses of beet observed, regardless of the treatment. Used correctly (in terms of speed and settings) and at the appropriate stages, mechanical weeding tools do not result in beet losses. However, they do limit performance, because the speed is reduced ( $3-4 \mathrm{~km} / \mathrm{h}$ for the hoe), and the opportunities to use the tools are also reduced because it is necessary to wait until the beet is sufficiently developed and the weather is ideal (dried soil and drying weather for three consecutive days). 
The cost of the different weed control schemes is presented in Table 5. The chemical programme was the most expensive ( $€ 320 / \mathrm{ha})$, mostly due to the product cost $(79 \%)$. The mechanical condition (M4) had the lowest cost ( $€ 180 /$ ha), due to the different number of passes required (three, compared with six for the chemical condition) and the fact that no herbicides were purchased. It should be noted that the manpower cost required for manual catch-up weeding was not taken into account.

The two mixed programmes had similar costs (€290/ha), because one hoeing pass (€51/ha) costs almost the same as spraying with herbicide (€53/ha).

Table 5. Costs for the different weeding treatments in $€ /$ ha

\begin{tabular}{|l|c|c|c|}
\hline Weeding treatments & $\begin{array}{c}\text { Products cost } € / \text { ha }(\% \\
\text { total })\end{array}$ & $\begin{array}{c}\text { Machines cost and labour } \\
\text { /ha }(\% \text { total })\end{array}$ & Total cost $€ /$ ha \\
\hline M1 - Chemical & $252(79 \%)$ & $68(21 \%)$ & 320 \\
\hline M2 - Mixed 1 & $187(65 \%)$ & $102(35 \%)$ & 289 \\
\hline M3 - Mixed 2 & $149(51 \%)$ & $142(49 \%)$ & 291 \\
\hline M4 - Mechanical & $0(0 \%)$ & $180(100 \%)$ & 180 \\
\hline
\end{tabular}

In terms of the yields measured for the four conditions, there were no significant differences between M1, M2 and M3, either for the net yield in $\mathrm{kg}$ of beet per hectare or $\mathrm{kg}$ of sugar/ha. However, the yield obtained for totally mechanical weeding was significantly lower than for the other three (Table 6). Differences in effectiveness do not necessarily result in a difference in yield, since the impact of weeds will depend not only on their numbers but also on their development. Thus, the lower effectiveness of chemical weed control did not have an impact on yield since the weeds were at less developed stages. This was not the case for M4, where weeds were not slowed down in their development and where the vast majority $(83 \%)$ were in the heading-flowering stage (BBCH 58-60) in June.

Table 6. Net yields (beets and sugar) for the four weeding treatments

\begin{tabular}{|l|c|c|}
\hline \multicolumn{1}{|c|}{ Weeding treatments } & Net Yield $(\mathrm{kg}$ of beets $/ \mathrm{ha})$ & Sugar yield $(\mathrm{kg}$ sugar/ha $)(\% \mathrm{M1})$ \\
\hline M1 - Chemical & 96111 & $18508(100 \%)^{\mathrm{a}}$ \\
\hline M2 - Mixed 1 & 95081 & $18105(97.82 \%)^{\mathrm{a}}$ \\
\hline M3 - Mixed 2 & 95301 & $17941(96.93 \%)^{\mathrm{a}}$ \\
\hline M4 - Mechanical & 77292 & $15007(81.09 \%)^{\mathrm{b}}$ \\
\hline
\end{tabular}

Means quoted with different letters are significantly different at the level $\mathrm{p}<0.05$.

\section{CONCLUSION}

The results of this trial show that it is possible to integrate mechanical weeding in chemical schemes in a very satisfactory manner in order to reduce the use of herbicides. In this trial, were the conditions including the use of mechanical tools to replace two or three rounds of spraying that proved the most effective, obtaining an identical yield to that obtained with completely chemical protection at slightly lower cost. The fully mechanical solution is not currently adequate; the problem lies exclusively in weed control in the crop row. This weed control scheme resulted in a sugar yield loss of almost $19 \%$ compared to chemical weed control, and will probably have an impact on future weed growth on the plot. A solution needs to be found that will make it possible either to 
take a more aggressive approach and thus accept the destruction of beets (denser seeding), or to increase the time lag between the beet stage and the weed stage. Another possibility is the combination of spraying directed at the crop row and hoeing between rows. As the weather conditions have a significant impact on plant development and the possibility of mechanical intervention, these results are specific to the year 2017. It is therefore important to continue this type of trial in order to carry out an evaluation over several years.

\section{ACKNOWLEDGEMENTS}

The authors would like to thank Mr Christian Pierard, the PVBC, La Raffinerie Tirlemontoise, Beneo Orafti, Cosucra and the Flemish and Walloon regions.

\section{REFERENCES}

Calvet R., Barriuso E., Bedos L., Benoit P., Charnay M.P., Coquet Y. (2005). Les pesticides dans le solConséquences agronomiques et environnementales. France Agricole Référence scientifique. 637 pages.

DGARNE (2014). Indicateurs clefs de l'environnement wallon 2014. SPW éditions. 204 pages.

ITAB (2012). Désherber mécaniquement les grandes cultures. Projet Casdar $n^{\circ} 8135.82$ pages.

ITB (2011). Désherbage mécanique combiné : quelques enseignements de l'année 2011. La technique betteravière $n^{\circ} 953 d u 20$ septembre 2011.3 pages.

Lievens E., Carrola S., Janssens L. et Bragard C. (2014). Estimation quantitative des utilisations de produits phytopharmaceutiques par les différents secteurs d'activité en Wallonie, Comité régional PHYTO, CORDER, 150 pages.

Colomb B., Aveline A., Carof M. (2011). Une évaluation multicritère qualitative de la durabilité de systèmes de grandes cultures biologiques, Quels enseignements? Restitution des programmes RotAB et CITODAB, Document d'analyse PSDR3 Midi-Pyrénées-Projet CITODAB. 42 pages.

Kunz C., Schröllkamp C., Koch H.J., Eßer C., Schulze Lammers P., Gerhards R. (2015). Potentials of post-emergent mechanical weed control in sugar beet to reduce herbicide inputs. Landtechnik 70(3), 2015, 67-81.

Pottier M., Bonin L., Leclech N. (2012). Désherbage mécanique, Un appui aux herbicides pour des efficacités aléatoires sur céréales d’hiver. Perspectives agricoles n³95 décembre 2012. p 12-16.

Rabier F., Miserque O., Pekel S., Dubois G., Noel H. (2008). Guide of running costs for farm equipment: a simple tool for decision-making. III International Scientific Symposium, Farm machinery and process management in sustainable agriculture.Gembloux, Belgium 12-13 Novembre 2008. Proceedings Tome 2. ISBN 978 -2-87286-061-6. p 43-50.

Mechant E., De Marez T., Hermann O., Olsson R., Buckle R. (2008). Target site resistance to metamitron in Chenopodium album L. Journal of plant diseases and protection, special issue XXI, ISSN 1861-405. Eugen Ulmer KG Stuttgart. p 37-40.

De Cauwer B., Cardinael A., Claerhout S., Manderyck B., Reheul D. (in press). Differential sensitivity of Atriplex patula and Chenopodium album to sugar beet herbicides: a possible cause for the upsurge of Atriplex patula in sugar beet fields. To be published in Weed Research. 